\title{
Analysis of Macroeconomics Effects on the Indonesian Sharia Stock Index
}

\section{SERAM BI \\ Received 24 May 2019 \\ Revised 12 Jun 2019 \\ Accepted 27 Jul 2019}

\author{
Anton Bawono*, Imamul Mutaqin \\ Faculty of Economy and Islamic Business, IAIN Salatiga, \\ Indonesia
}

\begin{abstract}
A bstract
Purpose- The purpose of this study was to analyze the response shown by the Indonesian Sharia Stock Index (ISSI) against the shock that occurred in inflation, IDR / USD exchange rate, interest rate, money supply (JUB), world oil prices and world gold prices.

M ethods- This research is quantitative research using the VAR model as data analysis. The data have been obtained and analyzed using Eviews software tool version 9.

Findings- These results indicate that the ISSI responded negatively and permanently against shock happens to inflation, ISSI responded negatively and permanently against the shock that occurred at the BI Rate, the ISSI responded positively and permanently to the shock that occurred in world oil prices, the ISSI responded positively and permanently to the shock that occurred at world gold prices.

Research implications- Investors should pay attention to changes that might occur in inflation, interest rate, world oil prices and world gold prices because in the results of this study show that the stock index will respond at least 10 months ahead when inflation, BI Rate, world oil prices and world gold prices experience shock. The government is expected to maintain economic stability so investors remain interested in investing in the domestic stock market
\end{abstract}

Keyw ords Macroeconomics, Sharia Stock Index Paper typeR esearch paper

\Email korespondensi: alfathbawono@gmail.com

\section{Pedoman Sitasi}

Anton Bawono \& Imamul Mutaqin (2019). Analysis Of Macro's Economic Variable Influence on Indonesia's Sharia Stock Index. SERAMBI, 1(2), 1-12

D OI: https:/ / doi.org/ 10.36407/ serambi.v1i2.66

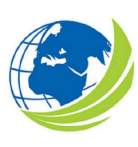

SERAMBI, Vol 1, No.2, Agustus 2019,

pp. 1 - 12

eISSN 2685-9904 


\section{Introduction}

Investment activities allow society to continuously improve economic activities and employment opportunities, increase national income and increase the level of prosperity of the community. Investment is divided into two, first direct investment such as entrepreneurship / managing your own business in the real sector (real sector) and secondly indirect investment in the non-real sector such as investment in Islamic banking (deposits) and markets Islamic capital through Islamic stock exchanges, Islamic mutual funds, Sukuk, SBSN, and others (Pardiansyah, 2017: 342).

One form of investment as described earlier is the capital market. The capital market, in general, can be interpreted as a market that sells products in the form of abstract funds. Whereas in its concrete form, products traded on the capital market are in the form of securities on the stock exchange. Conditions that occur in stock exchange are shown in the form of a stock index movement. The movement of the stock index reflects how the development of shares in it. Where the value of these shares is determined by the issuer and the attitudes/ decisions of its investors. Investors will usually give decisions related to any event/ thing related to their investment, both positive and negative decisions. One of the considerations of the investors discussed in this study is the events that occur in macroeconomic space.

There are important factors that can influence the development of the Islamic index, namely macroeconomic and monetary variables such as Sharia Indonesia Bank Certificates, inflation, the money supply (JUB), exchange rates and others. While internal factors that are able to influence are such as national economic conditions, security, political conditions, government policies and others (Ardana, 2016: 19).

This study aims to clarify the Indonesian sharia stock index (ISSI) response to the macroeconomic changes. Some macroeconomic factors such as inflation, IDR / USD exchange rate, interest rates, money supply (JUB), world oil prices and world gold prices are used to predict changes in ISSI. The research conducted by Suciningtias and Khoiroh (2015: 398-412) tudy show that inflation and exchange rates have a significant negative effect on ISSI while the Islamic Indonesia bank certificate and world oil prices do not have a significant effect on the ISSI.Afendi (2017: 48-71) indicate that interest rates and world oil prices have a significantly negative effect and the variable variable has a significant positive effect on JII, while the inflation variable has no significant effect.Purnamasari and Sukmana (2016) show that world oil prices and world gold prices significantly influence the Jakarta Islamic Index (III).Pasaribu and Firdaus (2013: 117-131) shows that inflation does not have a significant effect on the ISSI, while the interest rate has a significant positive effect on the ISSI.The research conducted by Beik and Fatmawati (2014: 155-178) shows that in the short term, only the Dow Jones Islamic Market Index of Japan and the Industrial Production Index (IPI) significantly influence the JII. Recently study by Robiyanto (2018) found that macroeconomic variables such as the USD / IDR rate and $\mathrm{BI}$ rate had a negative and significant effect on the Jakarta Islamic Index (III) return, while changes in the price of gold in IDR had a positive effect. While the study of Hamzah, Irmansah, $\&$ Azis (2018) only succeeded in proving simultaneous effects, but partially, macroeconomic variables did not have a significant effect on the Indonesian Islamic Stocks Return. This study can contribute to providing knowledge on the debate over the independence of the Islamic capital market from the macroeconomy which in previous studies still had different conclusions.

\section{Literature Review}

Portofolio Theory

Modern portfolio theory is based on the assumption that all investors are reluctant to risk. This theory teaches how to combine stocks into a portfolio to obtain maximum profit with minimal risk. Risk in investment sector can be avoided by diversifying stocks by forming a portfolio. A portfolio is a collection of financial assets in one unit held or made by an investor, investment company, or financial institution. In portfolio theory, risk is the level of deviation from expected profits. Risk in investment arises because of the uncertainty of time and the amount of return that investors will receive.

\section{Inflation}

There are two important meanings which are key in understanding inflation. The first is the price increase in general and the second is continuous, meaning that inflation must describe the increase in the price of a large number of goods and services used (or consumed) in an economy and not due to 
seasonal factors such as Eid.If inflation increases, the company's income and costs will increase. When the production costs increase higher than the company's income, the company's profitability will decrease. Then the dividends that will be received by shareholders will also decrease and end with investors withdrawing their funds from the company.

Exchange

The exchange is the price of one unit of a foreign currency in the domestic currency or can also be said as the price of a domestic currency against a foreign currency (Simorangkir and Suseno, 2004: 4). Depreciation of the domestic currency against foreign currencies will make changes in the amount of costs that will be incurred by companies, especially companies that are active in export import and investors will not be interested in investing in the domestic capital market because the depreciation of the domestic currency against foreign currencies indicates that prospects the domestic economy is bad and the cause of the weakening of the exchange rate could be due to the inadequate domestic economic fundamentals.

Interest Rate

interest rate is a policy interest rate that reflects the monetary policy stance or stance set by bank Indonesia and announced to the public. The increase in interest rates will change the sheet of investor portfolios, where investors tend to invest their funds in the form of deposits in the banking sector because the increase in interest rates will increase deposit income.

M oney Supply (JUB)

Money supply is the total amount of money officially issued by the central bank in the form of currency, as well as demand deposits and quasi money. The amount of money demanded for speculative purposes is negatively affected by interest rates. Cash requests for speculative purposes indicate the amount of cash requested for the purpose of financing speculative expenditure transactions such as stocks and bonds. so, the higher the interest rate causes the less amount of cash requested for the purpose of speculation and vice versa.

\section{World Oil Prices}

The price of crude oil is a benchmark for the value of crude oil that consumers charge for the benefits of crude oil. the rise in world oil prices will increase the prices of other commodities around the world which can increase inflationary pressures. unstable changes in world oil prices haunt stock trading activities where investment conditions are not conducive to capital markets (Suciningtias and Khoiroh, 2015: 400)

World Gold Prices

Gold is one of the world commodities that has been used as a payment instrument. The gold standard that is often used as a benchmark throughout the world is the price of the London gold market standard or commonly called London Gold Fixing (Gumilang et al., 2014: 3). Gold has a price that tends to increase and is one of the most liquid commodities. Gold can be the choice of investors in investing their funds if the risks arising from investments in the capital market are not compensated by the level of return earned and if the economic situation is unstable, gold can be a promising choice.

Indonesian sharia stock in dex (ISSI)

The Indonesian Sharia Stock Index (ISSI) is an index launched by IDX on May 12, 2011 where ISSI constituents are all sharia shares listed on the IDX and entered into the List of Sharia Securities (DES). ISSI constituents are re-selected twice a year, every May and November, following the DES review schedule. The ISSI calculation method follows the other BEI stock index calculation methods, namely the weighted average of market capitalization using December 2007 as the base year of the ISSI calculation

Conceptual framework and hypotheses

The research conducted by Ardana (2016: 17-28) entitled 'The Effect of Macroeconomic Variables on Islamic Stock Indices in Indonesia: ECM Model " with the research period May 2011 - September 2015. This study uses the Error Corection Model (ECM) as the method of analysis. The results of this study 
indicate that in the short term interest rates, inflation and world oil prices have no influence on the ISSI while the exchange rate and Indonesian sharia bank certificates have an influence on the ISSI, then in the long term variable interest rates, SBIS, exchange rates and prices world oil has an influence on the ISSI while inflation has no influence on the ISSI.

The research conducted by Suciningtias and Khoiroh (2015: 398-412) with the title "Analysis of the Impact of Macroeconomic Variables on the Indonesian Sharia Stock Index (ISSI)" where in this study used multiple linear regression as the method of analysis with the research period May 2011 November 2014. the results of the study show that inflation and exchange rates have a significant negative effect on ISSI while the Islamic Indonesia bank certificate and world oil prices do not have a significant effect on the ISSI.

The research conducted by Afendi (2017: 48-71) entitled 'The Effect of Macroeconomic Variables on Stock Indices in the Jakarta Islamic Index (III)" with the 2012-2016 research period. This study uses multiple linear regression as the method of analysis. The results of this study indicate that interest rates and world oil prices have a significantly negative effect and the variable variable has a significant positive effect on $\mathrm{JII}$, while the inflation variable has no significant effect.

Purnamasari and Sukmana (2016) which examine the effect of world oil prices and world gold prices on the Stock Index in the Jakarta Islamic Index (JII) in the Long and Short Term (January 2005December 2015) with the results of world oil prices and world gold prices significantly influence the Jakarta Islamic Index (JII).

The research was conducted by Pasaribu and Firdaus (2013: 117-131) entitled "Analysis of the Effect of Macroeconomic Variables on the Indonesian Islamic Stock Index" where Pasaribu and Firdaus used multiple linear regression analysis as a method in their research. The research objects studied were macroeconomic and ISSI variables for the period May 2011 - April 2013. This study shows that inflation does not have a significant effect on the ISSI, while the interest rate has a significant positive effect on the ISSI.

The research conducted by Beik and Fatmawati (2014: 155-178) with the title "Effect of International Sharia Stock Price Index and Macroeconomic Variables on the Jakarta Islamic Index" with the research period January 2017 - October 2012. This study uses the Vector Error Correction Model (VECM) as an analytical method. This study shows that in the short term, only the Dow Jones Islamic Market Index of Japan and the Industrial Production Index (IPI) significantly influence the JII. Whereas in the long run, the European Dow Jones Islamic Market Index, Malaysia's Dow Jones Islamic Market Index and Industrial Production Index (IPI) have a significant positive relationship to JII. The Dow Jones Islamic Market Index of Japan, the United States Dow Jones Islamic Market Index, the money supply (M2) and SBIS have a significantly negative relationship to the JII. Meanwhile, the Consumer Price Index (CPI), the BI Rate and the rupiah exchange rate against the US dollar do not have a significant relationship with JII.To make it easier to understand this research, the research framework was made as follows:

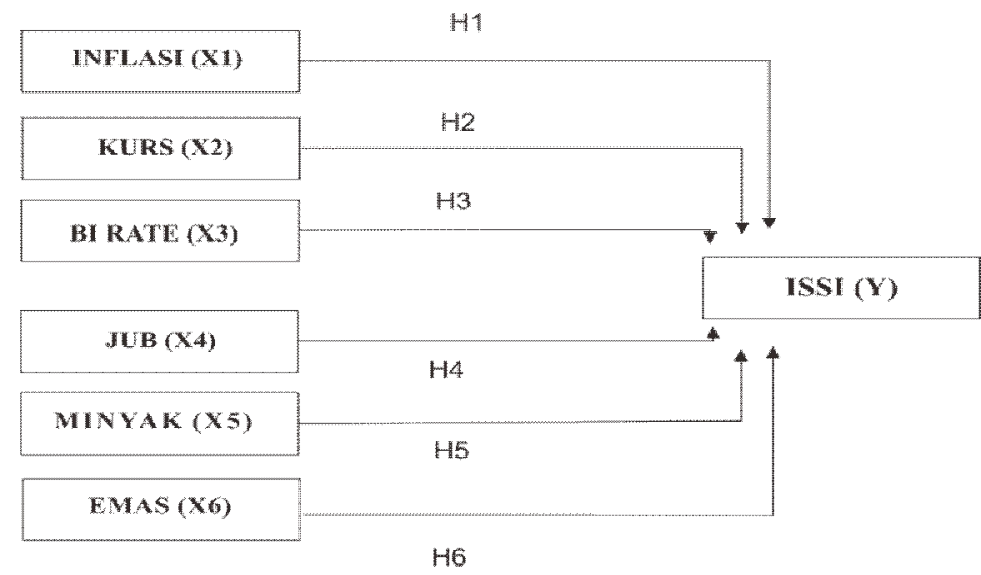

Figure 1. Research Model 
Anton Bawono \& Imamul Mutaqin / Macro's Economic Variable...

\section{Research M ethods}

The research data was collected from secondary sources through the institutional materials in the form of statistical related published by parties data. This study takes data at the end of each month from the variables being studied.Data in this study were collected from May 2011 to August 2018. In this study, the population is the Indonesian Syariah Stock Index (ISSI), Exchange Rate, Inflation, BI Rate, Money Supply (JUB), World Oil Prices and World Gold Prices

\section{Analytical technique}

The research uses Vector Autoregressive (VAR) analysis techniques. Juanda and Junaidi (2012: 138) the VAR model is a system of simultaneous equations, where all variables are considered as endogenous variables, then estimation can be done by applying the OLS method to each variable with an equation at each lag. This model has several steps, namely starioner test, classic assumption test, lag length criteria test, Johansen Cointegration test, stability of VAR model, Impulse Response Function, Forecast Error Decomposition Variance and causality test.

\section{Results and Discussion}

Stasionary test

The stationarity test in this study uses Augmented Dickey-Fuller (ADF). In the Augmented DickeyFuller (ADF) test, if the absolute value of t-ADF is greater than the absolute value of the MacKinnon Critical Values, the data is stationary at the specified level. Besides that, it can also be seen from its probability value. Following the results:

Table 1. Result of Stasionary test

\begin{tabular}{|l|c|l|c|c|}
\hline \multirow{2}{*}{ variable } & \multicolumn{2}{c|}{ Level } & \multicolumn{2}{c|}{ 1st Difference } \\
\cline { 2 - 5 } & probability & \multicolumn{1}{c|}{ Result } & probability & Result \\
\hline ISSI & 0.1870 & TidakStasioner & 0.0000 & Stasioner \\
\hline Inflation & 0.8637 & TidakStasioner & 0.0000 & Stasioner \\
\hline Excange & 0.6544 & TidakStasioner & 0.0000 & Stasioner \\
\hline Interest Rate & 0.3393 & TidakStasioner & 0.0000 & Stasioner \\
\hline JUB & 0.0009 & Stasioner & 0.0000 & Stasioner \\
\hline Oil Price & 0.7003 & TidakStasioner & 0.0000 & Stasioner \\
\hline Gold Price & 0.5825 & TidakStasioner & 0.0000 & Stasioner \\
\hline
\end{tabular}

Source : secondary data processed by Eviews 9

Table 1 show that,at the level, except the money supply, other variables have the probability value is $>0.05$ so that it can be conduded that the ISSI, inflation, Exchange Rate, BI Rate, Oil and Gold data are not stationary at the level so that stationary data is tested at the 1 difference level. At the level of 1 difference, it can be seen if the probability values are $<0.05$ so that it is stationary at the level of 1 difference

Lag Length C riteria test

The choice of optimal lag can be done by comparing the value of Adj. R squared VAR model with lag length according to candidates than suggested in the lag length criteria test, where the use is displayed lag with the results of Adj. The biggest $R$ squared VAR model will be chosen (Juanda and Junaidi, 2012: 151). 
Table 2. Result of Lag Length Criteria test

\begin{tabular}{|c|c|c|c|c|c|c|}
\hline Lag & LogL & LR & FPE & AIC & SC & HQ \\
\hline 0 & -9.165 .903 & NA & 23458.72 & 24.25238 & $24.40571^{*}$ & $24.31366^{*}$ \\
\hline 1 & -8.858 .755 & 56.57986 & $20216.35^{*}$ & 24.10199 & 25.02201 & 24.46967 \\
\hline 2 & -8.697 .014 & 27.66610 & 25721.93 & 24.33425 & 26.02096 & 25.00834 \\
\hline 3 & -8.528 .539 & 26.60142 & 32576.87 & 24.54879 & 27.00219 & 25.52929 \\
\hline 4 & -8.378 .612 & 21.69994 & 44200.11 & 24.81214 & 28.03223 & 26.09904 \\
\hline 5 & -8.166 .651 & 27.88958 & 52394.18 & 24.91224 & 28.89902 & 26.50555 \\
\hline 6 & -7.967 .939 & 23.53166 & 66816.66 & 25.04721 & 29.80068 & 26.94692 \\
\hline 7 & -7.778 .187 & 19.97391 & 91823.66 & 25.20576 & 30.72591 & 27.41188 \\
\hline 8 & -7.245 .884 & $49.02792 *$ & 54877.56 & 24.46285 & 30.74970 & 26.97538 \\
\hline 9 & -6.852 .225 & 31.07832 & 51891.22 & 24.08480 & 31.13834 & 26.90374 \\
\hline 10 & -6.557 .152 & 19.41269 & 72608.34 & 23.96619 & 31.78641 & 27.09153 \\
\hline 11 & -6.155 .020 & 21.16486 & 93282.13 & $23.56584^{*}$ & 32.15275 & 26.99759 \\
\hline
\end{tabular}

Source : secondary data processed by Eviews 9

Table2 shows that the candidates for the optimal lag are lag0, lag 1, lag 8 and lag 11. The following are the results of $A d j$. R squared with selected lag displays

Table 3. Result of A dj. R squared VAR

\begin{tabular}{|l|l|}
\hline Lag & Adf. R squered \\
\hline 0 & 0.000000 \\
\hline 1 & 0.003503 \\
\hline 8 & 0.256829 \\
\hline 11 & 0.205635 \\
\hline
\end{tabular}

Source : secondary data processed by Eviews 9

The selected lag candidate that will be used is lag 8 , later it will be used for further data analysis.

Johansen Cointegration test

Cointegration shows that there is a long-term relationship between variables. To know the cointegration or not, it can be done by looking at the statictic and max-eigen statistic trace values and comparing them with the critical value in the johansencointegration test. If the trace value of statictic and max-eigen statistic > critical value then there is a cointegration relationship.

Table 4. Result of Johansen Cointegration test

\begin{tabular}{|c|c|c|c|c|}
\hline \multicolumn{5}{|c|}{ Unrestricted Cointegration Rank Test (T race) } \\
\hline $\begin{array}{c}\text { Hypothesized } \\
\text { N o. of CE(s) }\end{array}$ & Eigenvalue & $\begin{array}{c}\text { Trace } \\
\text { Statistic }\end{array}$ & $\begin{array}{c}\mathbf{0 . 0 5} \text { Critical } \\
\text { Value }\end{array}$ & Prob.** \\
\hline None & 0.249539 & 67.68393 & 76.97277 & 0.2068 \\
\hline At most 1 & 0.213561 & 45.29263 & 54.07904 & 0.2391 \\
\hline At most 2 & 0.199167 & 26.55394 & 35.19275 & 0.3119 \\
\hline At most 3 & 0.062082 & 9.229872 & 20.26184 & 0.7146 \\
\hline
\end{tabular}


SERAMBI, 1(2), 1-12

Anton Bawono \& Imamul Mutaqin / Macro's Economic Variable...

\begin{tabular}{|c|c|c|c|c|}
\hline At most 4 & 0.052794 & 4.230649 & 9.164546 & 0.3789 \\
\hline \multicolumn{2}{|c|}{ Unrestricted Cointegration Rank Test (M aximum Eigenvalue) } \\
\hline $\begin{array}{c}\text { Hypothesized } \\
\text { N o. of CE(s) }\end{array}$ & Eigenvalue & $\begin{array}{c}\text { M ax-Eigen } \\
\text { Statistic }\end{array}$ & $\begin{array}{c}\mathbf{0 . 0 5} \text { Critical } \\
\text { Value }\end{array}$ & Prob.** \\
\hline None & 0.249539 & 22.39129 & 34.80587 & 0.6449 \\
\hline At most 1 & 0.213561 & 18.73869 & 28.58808 & 0.5134 \\
\hline At most 2 & 0.199167 & 17.32407 & 22.29962 & 0.2143 \\
\hline At most 3 & 0.062082 & 4.999223 & 15.89210 & 0.8884 \\
\hline At most 4 & 0.052794 & 4.230649 & 9.164546 & 0.3789 \\
\hline
\end{tabular}

Source : secondary data processed by Eviews 9

Table 4 shows that no cointegration found in this study is evident from the trace values of statictic and max-eigenstatistics <critical value which means there is no long-term relationship so that research can be continued with theVAR model in difference.

Stability of the VAR M odel

To support the validity of the IRF and FEDV tests, the VAR model estimation needs to be checked for stability

Table 5. Result of Stability VAR

\begin{tabular}{|c|r|l|r|}
\hline Root & Modulus & \multicolumn{1}{|c|}{ Root } & Modulus \\
\hline$-0.347333+0.882139 i$ & 0.948055 & $0.808552+0.424185 i$ & 0.913066 \\
\hline$-0.347333-0.882139 i$ & 0.948055 & $0.808552-0.424185 i$ & 0.913066 \\
\hline $0.897209-0.294118 i$ & 0.944187 & $0.188894-0.884505 i$ & 0.904451 \\
\hline $0.897209+0.294118 i$ & 0.944187 & $0.188894+0.884505 i$ & 0.904451 \\
\hline $0.519889-0.782273 i$ & 0.939274 & $0.877132+0.117549 i$ & 0.884974 \\
\hline $0.519889+0.782273 i$ & 0.939274 & $0.877132-0.117549 i$ & 0.884974 \\
\hline$-0.071718+0.928388 i$ & 0.931154 & $0.582261+0.665031 i$ & 0.883908 \\
\hline$-0.071718-0.928388 i$ & 0.931154 & $0.582261-0.665031 i$ & 0.883908 \\
\hline$-0.902280+0.221819 i$ & 0.929146 & $-0.752923+0.458472 i$ & 0.881527 \\
\hline$-0.902280-0.221819 i$ & 0.929146 & $-0.752923-0.458472 i$ & 0.881527 \\
\hline $0.750667-0.530940 i$ & 0.919455 & $0.345998-0.803773 i$ & 0.875080 \\
\hline $0.750667+0.530940 i$ & 0.919455 & $0.345998+0.803773 i$ & 0.875080 \\
\hline$-0.713088+0.577078 i$ & 0.917341 & $-0.113083-0.861047 i$ & 0.868441 \\
\hline$-0.713088-0.577078 i$ & 0.917341 & $-0.113083+0.861047 i$ & 0.868441 \\
\hline$-0.909552+0.116033 i$ & 0.916924 & $-0.497643-0.703840 i$ & 0.861998 \\
\hline$-0.909552-0.116033 i$ & 0.916924 & $-0.497643+0.703840 i$ & 0.861998 \\
\hline $0.418889-0.815117 i$ & 0.916452 & $-0.408779+0.748281 i$ & 0.852657 \\
\hline $0.418889+0.815117$ & 0.916452 & $-0.408779-0.748281 i$ & 0.852657 \\
\hline$-0.814178+0.420499 i$ & 0.916354 & $0.683865+0.214857 i$ & 0.716823 \\
\hline$-0.814178-0.420499 i$ & 0.916354 & $0.683865-0.214857 i$ & 0.716823 \\
\hline & No root lies outside the unit circle. & \\
\hline & VAR satisfies the stability condition. & \\
\hline Sour & & & \\
\hline
\end{tabular}

Source : secondary data processed by Eviews 9 
The analysis results shown in table 5 show that modulus $<1$ so the model is stable and shows that the IRF and FEDV test results are valid

Impulse Response Function (IRF)

The ISSI variable responds negatively to the inflation variable in period $2(-0.776607)$ then the ISSI responds positively to period 3 (0.385621) and 4 (1.577622). The next period 5-10 ISSI responds negatively to inflation except in period 7. Shock caused by variable interest rates makes the ISSI respond positively to the initial period of periods 2-4 with values that always increase from 0.030234 to 1.192359 and for periods 5-10 ISSI only gives negative responses with fluctuating values. The ISSI response due to the shock caused by oil prices shows a positive response in the 2-4 period with a value that decreases from 1.454638 to 0.527812 and becomes a negative ratio in period 5 with a value of -0.822853 then responds positively again with a value of 0.231329 in period 6 . In period $7-8$ occurs in a negative response with an increase of -0.236648 up to -0.523902 and in the period $9-10$ responds positively with a declining value.

Table 6. Result of Impulse Response Function (IRF)

\begin{tabular}{|c|c|c|c|c|c|}
\hline $\begin{array}{l}\text { Response of D(ISSI): } \\
\text { Period }\end{array}$ & $\mathrm{D}(\mathrm{ISSI})$ & D(INFLASI) & $\mathrm{D}\left(\mathrm{BI} \_\mathrm{RATE}\right)$ & $D(M I N Y A K)$ & ) $\mathrm{D}(\mathrm{EMAS})$ \\
\hline 1 & 4.728847 & 0.000000 & 0.000000 & 0.000000 & 0.000000 \\
\hline 2 & 1.212225 & -0.776607 & 0.030234 & 1.454638 & 0.936362 \\
\hline 3 & 1.398463 & 0.385621 & 0.179487 & 0.813928 & 0.164784 \\
\hline 4 & -1.334580 & 1.577622 & 1.192359 & 0.527812 & -0.436543 \\
\hline 5 & -0.256374 & -0.779520 & -1.905258 & -0.822853 & -0.570574 \\
\hline 6 & -0.556946 & -0.359500 & -0.302818 & 0.231329 & 1.628590 \\
\hline 7 & -1.494228 & 0.631661 & -0.569757 & -0.236648 & 1.028723 \\
\hline 8 & -0.562698 & -0.637688 & -0.095811 & -0.523902 & 0.312644 \\
\hline 9 & 0.397835 & -0.233314 & -0.408133 & 0.966401 & 0.264138 \\
\hline 10 & -0.426780 & -0.323808 & -0.392045 & 0.046259 & -0.306020 \\
\hline
\end{tabular}

Source : secondary data processed by Eviews 9

From 0.966401 it drops to 0.046259 . the gold price gave a shock to the ISSI so that the ISSI variable responded positively to period $2(0.936362)$ and period $3(0.164784)$. The ISSI variable only gives a negative response in period $4(-0.436543)$, period $5(-0.570574)$ and period $10(-0.306020)$ then in the period 6-9 all shows a positive response with values decreasing from 1.628590 to 0.264138 .

Forecast Error Decomposition V ariance (FEDV)

The inflation variable shows a contribution in period 2 of $2.19 \%$ and continues to remember until period 5 of $9.22 \%$. Period 6 had declined to $8.84 \%$ and then increased again to period 8 by $9.54 \%$ and became the highest contribution for 10 periods. In period 9 it decreased to $9.39 \%$ then increase in period 10 to $9.49 \%$.Interest rate variables provide very small contributions at the beginning of the period seen with values in period 2 of $0.003 \%$ and period 3 of $0.11 \%$ where not even up to $1 \%$. In period 4, the contribution began to improve, which was 3.99\% and in period 5 the BI Rate gave the highest contribution for 10 periods, which was $12.18 \%$ and then decreased to period 8 to $10.99 \%$.

The oil price variable in period 2 shows the contribution of $7.71 \%$, this is the contribution of the largest independent variable in the initial period. In the period 3-6, fluctuations began from $9.18 \%$, down to $8.39 \%$ and rose again to $8.95 \%$, then returned to $8.42 \%$. Period 9 becomes the period with the highest contribution from the variable oil price which is equal to $9.80 \%$ and ends in period 10 with a contribution of $9.70 \%$.Period 2-5 on the variable contribution value of gold prices ranged from $3 \%$ and in period 6 increased to $9.05 \%$. The highest contribution to the variable price of gold occurred in period 7 of $10.46 \%$, in the following period it tended to fluctuate stably and dosed with a contribution of $10.35 \%$ in period 10 . 
SERAMBI, 1(2), 1-12

Anton Bawono \& Imamul Mutaqin / Macro's Economic Variable...

Table 6. Result of Forecast Error D ecomposition V ariance (FEDV)

\begin{tabular}{ccccccc}
\hline \multirow{2}{*}{$\begin{array}{c}\text { Variance } \\
\begin{array}{c}\text { Decompositio } \\
\text { n of D(ISSI): }\end{array} \\
\text { Period }\end{array}$} & S.E. & D(ISSI) & I) & D(BI_RATE) & K) & D(EMAS) \\
\hline \hline 1 & 4.728847 & 100.0000 & 0.000000 & 0.000000 & 0.000000 & 0.000000 \\
2 & 5.237200 & 86.88660 & 2.198895 & 0.003333 & 7.714564 & 3.196608 \\
3 & 5.500410 & 85.23417 & 2.484991 & 0.109504 & 9.183589 & 2.987745 \\
4 & 6.034516 & 75.70506 & 8.899296 & 3.995152 & 8.394903 & 3.005591 \\
5 & 6.459211 & 66.23461 & 9.223955 & 12.18765 & 8.950137 & 3.403653 \\
6 & 6.705099 & 62.15574 & 8.847308 & 11.51411 & 8.424766 & 9.058067 \\
7 & 7.002069 & 61.54917 & 8.926559 & 11.22026 & 7.839527 & 10.46448 \\
8 & 7.080511 & 60.82452 & 9.540991 & 10.99134 & 8.214270 & 10.42888 \\
9 & 7.177508 & 59.49890 & 9.390526 & 11.01961 & 9.806628 & 10.28434 \\
10 & 7.214784 & 59.23559 & 9.495175 & 11.20131 & 9.709668 & 10.35825 \\
\hline \hline
\end{tabular}

Source : secondary data processed by Eviews 9

Granger Causality test

Variables are said to have a relationship in this causality test if the probability value is $\varangle 0.05$ if it is greater, meaning that it does not have a causality relationship.

Table 7. Result of Granger Causality test

\begin{tabular}{|c|c|c|c|}
\hline Null Hypothesis: & Obs & F-Statistic & Prob. \\
\hline INFLASI does not Granger Cause ISSI & \multirow{2}{*}{80} & 1.78780 & 0.0962 \\
\hline ISSI does not Granger Cause INFLASI & & 1.09994 & 0.3754 \\
\hline BI_RATE does not Granger Cause ISSI & \multirow{2}{*}{80} & 1.51218 & 0.1710 \\
\hline ISSI does not Granger Cause BI_RATE & & 0.59788 & 0.7760 \\
\hline MINYAK does not Granger Cause ISSI & \multirow{2}{*}{80} & 0.35075 & 0.9420 \\
\hline ISSI does not Granger Cause MINYAK & & 0.47532 & 0.8691 \\
\hline EMAS does not Granger Cause ISSI & \multirow{2}{*}{80} & 3.33215 & 0.0031 \\
\hline ISSI does not Granger Cause EMAS & & 0.84142 & 0.5700 \\
\hline
\end{tabular}

Source : secondary data processed by Eviews 9

The results of the causality test focused on the relationship between the independent and dependent variables where only the gold variable has a one-way significant relationship to the ISSI variable, as evidenced by the probability of gold which is $0.0031<0.05$, while the other variables are greater than 0.05 so the variable inflation, interest rates and oil prices do not have a two-way or one-way relationship with the ISSI.

Relationship between inflation and ISSI

Impulse Response Function test, ISSI addresses fluctuating responses, where there is a negative response at period 2, period 5, period 6, period 8, period 9 and period 10 then interspersed with positive responses in period 3, period 4 and period 7 , as a whole ISSI more often shows a negative response than positive so that it can be said that the ISSI responds negatively to changes in inflation. The fluctuation is followed by a value that gets smaller but does not refer to the number of stable changes close to 0 or the balance point. This means that if there is a shock in the inflation variable, it will negatively affect the ISSI, which is consistent with the research conducted by Sunardi and Ula (2017: 40), Suciningtias and Khoiroh (2015: 410), Heryanto (2016: 158), Ningsih and Alert (2018: 257) 
and Sanjaya and Pratiwi (2018: 9) which show that inflation has a negative effect on the stock index. Then the ISSI variable will continue to respond for at least more than 10 future periods.

Forecast Error Decomposition Variance (FEDV) test shows that the shock in the inflation variable contributes to the biggest ISSI change given in period 8 with a contribution of $9.54 \%$. In the 4 10 period, the level of contribution that was quite stable was seen near the highest contribution. This means that inflation has a role in the changes that occur in the ISSI at a maximum of $9.54 \%$ with a negative influence.

Relationship between interest rate and ISSI

Impulse Response Function test shows the ISSI responds positively to the shock at the interest rate at the beginning of the period then in period 5 gives a negative response to period 10, overall the ISSI more often shows a negative response than positive so it can be said that the ISSI responds negatively to changes at the interest rate, which is in accordance with the research conducted by Utami and Herlambang (2016: 83), Widyasa and Worokinasih (2018: 126-127), Harsono and Worokinasih (2018: 108) and Kumalasari et al (2016: 136) who shows the result that the interest rate has a negative effect on the stock index. If seen from the changes that occur do not show signs of going towards the equilibrium value so that it can be said that the ISSI will still respond to the shock from interest rates to the next 10 periods even though it will decrease.

The Forecast Error Decomposition Variance (FEDV) test shows a very small contribution by the interest rate at the beginning of the period but there is a significant increase in contribution in period 5 (12.2\%) and continued to be followed by a steady contribution to period $10,11 \%-12 \%$ with period 5 as the peak interest rate contribution to ISSI changes. This means that the interest rate has a role in the changes that occur in the ISSI at a high of $12.2 \%$ with a negative influence.

Relationship between world oil prices and ISSI

Impulse Response Function test addresses the results of the ISSI variable more often addressing a positive response than negative towards changes in fluctuating world oil prices and does not lead to a balance value which means that the ISSI will continue to respond to world oil prices for the next 10 perodes. This is in line with the results of the research conducted by Ardana (2016: 28), Pardede et al (2016: 137), Purnamasari and Sukmana (2017: 529), Hutapea (2014: 32) and Stake and Rate (2016: 332) which indicate World oil prices have a positive influence on the ISSI, where a positive influence can occur because rising oil prices will trigger an increase in mining prices, which in turn will increase the company's revenue in the mining sector, which is positively welcomed by investors and results in rising stock prices and stock indices. The increase in oil prices is based on increasing demand rather than reduced supply, the increase in world oil prices is motivated by the increase in world oil consumption.In the Forecast Error Decomposition Variance (FEDV) test the largest contribution was given in the 9th period at $9.80 \%$ with almost the whole contributing stable at $8 \%-9 \%$. This means that world oil prices have a role in the changes that occur at the highest ISSI of $9.80 \%$ with a positive influence.

Relationship between world gold prices and ISSI

The Impulse Response Function test shows that the ISSI tends to give a positive response to the negative response to the shock of world gold prices and does not indicate a change towards a balance number which means that the ISSI will continue to respond to changes in world gold prices for the next 10 periods. This is in line with the research conducted by Gumilang et al (2014: 8), Sunarjanto (2012: 161), Purnamasari and Sukmana (2017: 529), which shows that the world gold price has a positive effect on the stock index. Positive influence occurs because when the price of gold rises to eat it will increase the company's income in the mining sector, especially the type of gold and this makes investors prefer to invest their capital in the company rather than investing in the commodity directly. Forecast Error Variance Decomposition test (FEDV) shows the contribution at the beginning of the period which is a period of 2-5 showed only $3 \%-5 \%$ and then increased to $9 \%$ in the period 6 as well as the largest contribution occurred in the period 7 to contributing $10.46 \%$ and continues to be followed stable contribution to period 10 . This means that the world gold price has a role in the changes that occur in the ISSI highest of $10.46 \%$ with a positive influence. 


\section{Conclusions}

The Impulse Response Function Test results show that: (1) ISSI responds negatively to the shock that occurs in inflation and has not shown a move towards the equilibrium number; (2) ISSI responds negatively to the shock that occurs at the interest rate and has not shown a move towards the equilibrium number. (3) ISSI responds positively to the shock that occurs in world oil prices and has not shown a move towards the equilibrium number. (4) ISSI responds positively to the shock that occurred at the world gold price and has not shown a move towards the equilibrium number.

The results of the Forecast Error Decomposition Variance (FEDV) test show that: (1) Inflation showed the largest contribution to ISSI changes of $9.54 \%$ in period 8 . (2) Interest rate shows the largest contribution to ISSI changes of $12.18 \%$ in period 5. (3) World oil prices showed the largest contribution to ISSI changes of $9.8 \%$ in period 9. (4) World gold prices showed the largest contribution to ISSI changes of $10.46 \%$ in period 7 .The results of the granger causality test show only the world gold price variable which has a causality relationship to the ISSI and is a one-way relationship. The inflation variable, the BI Rate and world oil prices do not show causality with theISSI.

Implications

For investors. Investors should pay attention to changes that might occur in inflation, interest rate, world oil prices and world gold prices because in the results of this study show that the stock index will respond at least 10 months ahead when inflation, BI Rate, world oil prices and world gold prices experience shock.The IRF and FEDV tests show a volatile ISSI response and a stable contribution from inflation,interest rate, world oil prices and world gold prices that have experienced shocks, the government is expected to maintain economic stability so investors remain interested in investing in the domestic stock market.

Suggestion for further research

Subsequent research can use more diverse variables, be it macroeconomic variables that have not been used in this study or can also be financial management factors of companies in the stock market itself.Researchers can also make comparisons between domestic Islamic stocks and Islamic stocks that are outside the country.Researchers who want to use the interest rate should use the profit sharing ratio as a variable because it is more in line with the object of research that is based on sharia.

\section{References}

Afendi, A. (2017). Pengaruh Variabel Makro Ekonomi terhadap Indeks Saham di Jakarta Islamic Index (III). Jurnal $M$ anajemen dan Bisnis $V$ olume $13, \mathrm{~N} 0.2,48-71$.

Ardana, Y. (2016). Pengaruh Variabel Makro Ekonomi terhadap Indeks Saham Syariah di Indonesia: Model ECM. Jurnal Bisnis dan M anajemen Vol. 6 N 0.1, 17-28.

Beik, I. S., \& Fatmawati, S. W. (2014). Pengaruh Indeks Harga Saham Syariah Internasional dan Variabel Makro Ekonomi Terhadap Jakarta Islamic Index. A I-Iqtishad: V ol. VI N 0. 2, 155-178.

Kalengkongan, N. C., \& Rate, P. V. (2016). Pengaruh Faktor Makro Ekonomi terhadap Indeks Harga Saham Gabungan di Indonesia (IHSG) dan Jepang (NIKKEI 225) Periode 2011 - 2015. Jurnal Berkala IImiah Efisiensi Vol. 16 N 0. 03, 321-333.

Kumalasari, R., Hidayat, R. R., \& Azizah, D. F. (2016). Pengaruh Nilai Tukar, BI Rate, Tingkat Inflasi dan Pertumbunhan Ekonomi terhadap Indeks Harga Saham Gabungan (Studi Pada Indeks Harga Saham Gabungan Di BEl Periode Juli 2005-Juni 2015). Jurnal Administrasi Bisnis Vol. 34 N 0. 1, 130-137.

Sunardi, N., \& Ula, L. N. (2017). Pengaruh BI Rate, Inflaasi dan Kurs terhadap Indeks Harga Saham Gabungan (IHSG). Jurnal Sekuritas, V ol.1, N 0.2, 27-41.

Basuki, A. T. (2017). Pengantar Ekon ometrika. Yogyakarta: Danisa Media.

Bawono, A. (2006). M ultivarite A nalysis dengan SPSS. Salatiga: STAIN Salatiga Press.

Gumilang, R. C., Hidayat, R. R., \& Endang NP, M. G. (2014). Pengaruh Variabel Makro Ekonomi, Harga Emas dan Harga Minyak Dunia terhadap Indeks Harga Saham Gabungan. Jurnal Administrasi Bisnis Vol. 14 N o. 2, 1-9. 
Harsono, A. R., \& Worokinasih, S. (2018). Pengaruh Inflasi, Suku Bunga dan Nialai Tukar Rupiah terhadap Indeks Harga Saham Gabungan (Studi pada Bursa Efek Indonesia Periode 2013-2017). Jurnal Administrasi Bisnis V ol. 60 No. 2, 102-110.

Heryanto. (2016). analilis pengaruh tingkat inflasi, nilai kurs, harga emas dunia terhadap indek saham LQ45 di bursa efek indonesia periode tahun 2011-2014. Jurnal FinA cc V ol. 1 N 0. 1, 148-160.

Hutapea, G., Elvania Margareth, E., \& Tarigan, L. (2014). Analisis Pengaruh Kurs USD/ IDR, Harga Minyak, Harga Emas terhadap Return Saham (Studi Kasus pada BEI Periode 2007-2011). Jurnal IImiah V olume $18 \mathrm{~N} \mathrm{0.2,23-33.}$

Juanda, B., \& Junaidi. (2012). Ekonometrika Deret Waktu. Bogor: IPB Press.

Ningsih, M. M., \& Waspada, I. (2018). Pengaruh BI Rate dan Inflasi terhadap Indeks Harga Saham Gabungan (Studi Pada Indeks Properti, Real Estate, dan Building Construction, di BEI Periode 2013 - 2017). M anajerial, V ol. 3 N 0.5, 247-258.

Pardede, N., Hidayat, R. R., \& Sulasmiyati, S. (2016). Pengaruh Harga Minyak Mentah Dunia, Inflasi, Suku Bunga (Central Bank Rate), dan Nilai Tukar (Kurs) terhadap Indeks Harga Saham Sektor Pertambangan di ASEAN. Jurnal A dministrasi Bisnis V ol. 39 N 0.1, 130-138.

Pardiansyah, E. (2017). Investasi dalam Perspektif Ekonomi Islam: Pendekatan Teoritis dan Empiris. Jurnal Ekonomi Islam - Vol. 8, No. 2 , 337-373.

Pasaribu, R. B., \& Firdaus, M. (2013). Analisis Pengaruh Variabel Makro Ekonomi terhadap Indeks Saham Syariah Indonesia. Jurnal Ekonomi \& Bisnis V ol. 14, N 0. 1, 117-131.

Pratiwi, A. E., Dzulkirom, M., \& Azizah, D. F. (2014). Analisis Investasi Portofolio Saham Pasar Modal Syariah dengan Model Markowitz dan Model Indeks Tunggal. Jurnal Administrasi Bisnis Vol. 17 N 0. 1, 1-10.

Purnamasari, D., \& Sukmana, R. (2017). Pengaruh Harga Emas Dunia, Harga Minyak Mentah Dunia dan Indeks Produksi Industri terhadap Indeks Saham di Jakarta Islamic Index (III) dalam Jangka Panjang dan Jangka Pendek (Periode Januari 2005-Desember 2015). Jurnal Ekonomi Syariah Teori dan Terapan Vol. 4 N 0. 7, 515-530.

Suciningtias, S. A., \& Khoiroh, R. (2015). Analisis Dampak Variabel Makro Ekonomi terhadap Ideks Saham Syariah Indonesia (ISSI). CBA M V ol. 2 N 0.1, 398-412.

Sunarjanto. (2012). Pengaruh Inflasi, Kurs, Harga Emas dan Suku Bunga SBI terhadap Indeks Harga Saham Gabungan (IHSG) pada Bursa Efek Indonesia Periode 2006-2010. Fokus M anajerial Vol. 11, N o. 2, 155 - 163.

Utami, A. T., \& Herlambang, L. (2016). Pengaruh Variabel Makro Ekonomi terhadap Indeks Jakarta Islamic Index (III) Periode Januari 2010 hingga November 2015. Jurnal Ekonomi Syariah T eori dan Terapan Vol. 3 N o. 1, 70-84.

Widyasa, V. I., \& Worokinasih, S. (2018). Pengaruh Tingkat Inflasi, Nilai Tukar Rupiah, dan Tingkat Suku Bunga Domestik terhadap Indeks Saham Syariah Indonesia (ISSI) (Studi pada Saham Syariah yang Terdaftar di Bursa Efek Indonesia Periode 2013- 2017). Jurnal Administrasi Bisnis Vol. 60 N o. 1, 119-128.

\section{Author Profile}

Anton Bawono holds a doctorate from Sunan Kalijaga State Islamic University Yogyakarta. He began his career as a lecturer at the Faculty of Economics and Islamic Business at IAIN Salatiga, and currently serves as Dean at the Faculty of Economics and Islamic Business. Anton Bawono then joined the Indonesian Higher Education National Accreditation Body as an Assessor Member and was tasked with assessing the accreditation of study programs at the Faculty of Economics and Business in Indonesia. 